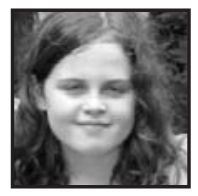

\title{
Commentary: \\ Recesses of the Young Poetic Mind
}

\section{Sophie Hillcoat}

\section{ABSTRACT}

In this interview young poet Sophie Hillcoat shares her story of how she began writing poetry during recess. She talks of her sources of inspiration and the important role that her friends play in contributing to her creative process. She has suggestions for young people who would like to start writing poetry as well as for teachers who teach poetry. Finally, she reads one of her poems.

Can you tell us when and how you first became interested in poetry?

first became interested in poetry at the start of grade five when I had the idea for my first poem. I read a lot of books and so I get ideas, sometimes randomly. And I decided to start writing that but I had homework so I couldn't do it at home. So I started during recess at school and I wrote a few poems there and then I stopped for a while. Then I got an idea for another one and that's how I really got interested in it and that's how it turned out.

\section{How long have you been writing poetry?}

I've been writing poetry since the start of grade five. I haven't really been doing it very long I'd say and I haven't done it in a while because I haven't had many ideas lately but in grade 5 it really was something that I did every recess. 
Can you share with us how you get an idea for a poem and then how you actually create the poem?

Well, the idea for quite a few of my poems came from the Percy Jackson series which is a story that has to do with the Greek gods and that's how I learned a lot of Greek mythology. And because of that I had the idea for many poems drawing from and interlocking with different creatures that I learned about and different gods or whatever that appeared in that story.

\section{When you create a poem, what do you do?}

Well, I guess I have to wait until recess. I first write down the story, the poem, and once I start it gets easier but I don't do it alone. I have friends who watch me write the poem and then if I can't find a word I'll ask, "Who knows what rhymes with the word before that?" and I get a bunch of different answers and I'll make up a sentence with the answer that I like the most.

\section{What do you do with your poems after you write them?}

I kept them in a pocket folder that I read over and as this activity became more popular and more kids realized what I was doing, somebody would ask for my pocket folder to read. So it spent time in my bin at the back of the class with a lot of other things and then l'd take it out for recess, bring a dictionary and a pencil and an eraser and l'd write it down.

\section{What is it about poetry that you particularly like?}

I like the way I connect with the creatures and how I can fall into the story that I'm weaving and yet be able to know what's ahead and be able to decide what I want. A book is interesting except, and I like the mysteries except, that you can't really change it. You're making up your own stories when you write poems and I enjoy that.

\section{What would you suggest to a friend if she wanted to start writing poetry?}

I would suggest that you need to have the subject and maybe the first lines before you started writing it and I would suggest that you know what kind of poem 
you're writing first. The poems that I write it's AA BB, meaning the first two lines the last words rhyme and then the second two they rhyme again, but they are on the same subject. So that's what I would recommend.

What would you suggest to teachers to get students writing poetry?

Well, I would suggest not to make too many restrictions because that would keep other children from showing their creativity and freedom in making the poems, the freedom is what makes it better and what really makes it something special.

You spoke about involving your friends in your poetry writing. Can you explain why that is helpful and important?

Well it is helpful because they help me a lot to write my poetry and they give me ideas. Plus I don't like taking everything for myself. I like giving credit to other people, which I also like to do when presenting my poems. It's very important to me for those reasons. There are a few friends who are more deeply involved in it. I have a friend named Lily who will outline things in black because she wants to help me and we have a lot of fun. And sometimes she'll suggest lines or something to write about and that's also very important and special.

\section{The Messenger}

With a beautiful but terrible cry

A shadow reaches toward the sky

The rhythmic song of its wings

The beat of the song it sings

Oh mother nature shining bright

Goddess of day, goddess of night

Man is here

He brings nothing but fear

Then with a terrible sound

It falls to the ground

The hawk is dead, the messenger gone. 


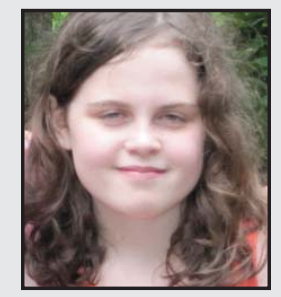

Sophie Hillcoat attends an elementary school in Montreal. She loves to read, preferring fantasy adventures over other genres. She enjoys writing poetry and fiction and has several unfinished novels on the go. She also loves to do anything artistic, bake, hike, ski, snowboard and camp with her family and friends. She has a dog named Jasper and a cat named Caramel. Sophie plans to be both a veterinarian and an author when she grows up. 